\title{
Human Anti-CD30 CAR-expressing Autologous T-lymphocytes
}

National Cancer Institute

\section{Source}

National Cancer Institute. Human Anti-CD30 CAR-expressing Autologous T-lymphocytes. NCI Thesaurus. Code C156933.

A preparation of autologous T-lymphocytes that have been genetically modified to express a chimeric antigen receptor (CAR) consisting of a single chain variable frag ment (scFv) derived from a human anti-CD30 monoclonal antibody, with potential immunostimulating and antineoplastic activities. Upon administration, the human antiCD30 CAR-expressing autologous T-lymphocytes specifically recognize and bind to CD30-expressing tumor cells, resulting in tumor cell lysis. CD30, a cell surface receptor and a member of the tumor necrosis factor (TNF) receptor superfamily, is transiently expressed on activated lymphocytes and is constitutively expressed in hematologic malignancies. Compared to CAR-T cells that use murine scFv-based CARs, CAR-T cells containing CARs with human SCFv regions reduces the immunog enicity of the CAR-T cells and may improve their long evity. 